\title{
PENDAPAT AL-MAZÂHIB AL-ARBA'AH TENTANG BENTUK SYIRKAH DAN APLIKASINYA DALAM PERSEROAN MODERN
}

\author{
Burhanuddin Susamto \\ Fakultas Syariah UIN Maulana Malik Ibrahim Malang \\ burhanuddins.uin@gmail.com
}

\begin{abstract}
Abstrak
The practice of sharia principles in our life is a necessity. A corporation as a part of life is not out of the frame of sharia perspective. The desire to view the corporation from the sharia perspective is starting from the fact that in figh muamalah there are some relevant contract, especially syirkah contract. Al-mazâhib al-arba'ah through their books of fiqh have introduced the similarities and differences of opinion concerning shirkah forms which original law is allowed according to the Qur'an, the Sunnah and ijma'. Therefore, through this article, the author will reveal again the opinion of the each schools concerning syirkah forms and how to implement it in the context of a modern corporation.
\end{abstract}

Mengamalkan prinsip-prinsip syariah dalam kehidupan kita merupakan suatu keniscayaan. Perseroan bisnis sebagai bagian dari kehidupan pun tidak lepas dari jangkauan perspektif syariah. Keinginan untuk melihat perseroan dari perspektif syariah adalah berangkat dari kenyataan bahwa dalam fiqh muamalah terdapat beberapa akad yang relevan, terutama akad syirkah. Al-mazâhib al-arba'ah melalui kitab-kitab fiqhnya telah memperkenalkan persamaan dan perbedaan pendapat bentuk-bentuk syirkah yang pada dasarnya hukum asalnya boleh menurut al-Qur'an, as-Sunnah dan ijma'. Karena itu melalui artikel ini, penulis akan mengungkapkan kembali pendapat masing-masing mazhab tentang bentuk-bentuk syirkah dan bagaimana mengimplementasikannya dalam konteks perseroan modern.

Kata Kunci: Syirkah, Mazhab, Perseroan

Pada dekade belakangan ini telah tumbuh kesadaran kuat untuk menegaskan kembali identitas keislaman. Salah satu bentuk manifestasi adalah munculnya desakan dari sebagian umat Muslim yang berpandangan bahwa semua institusi kehidupan seharusnya disesuaikan dengan prinsip-prinsip Islam. Kebutuhan untuk mengeksplorasi prinsipprinsip Islam relevan bagi institusi-institusi, termasuk pengembangan ide cemerlang terkait bagaimana prinsip-prinsip itu dapat diterapkan di tengah situasi perubahan era sekarang. ${ }^{1}$ Diantara institusi modern yang relevan untuk menerapkan prinsip-prinsip syariah adalah

\footnotetext{
${ }^{1}$ Imran Ahsan Khan Nyazee, Islamic Law of Business Organization (Partnerships), (Pakistan: The International of Islamic Thought, 2000), h. 1.
}

perseroan. Perseroan yang menjalankan kegiatan usaha berdasarkan prinsip syariah disebut perseroan syariah.

Penyebutan istilah "syariah" secara legal formal, baik pada tataran konsep maupun penerapannya, merupakan langkah penting. Begitupula sebaliknya, memaknai syariah hanya sebatas pada nilai-nilai etika atau moral semata, tidak akan mempunyai daya perubahan. ${ }^{2}$ Upaya perubahan ini perlu dilakukan, mengikat selama ini ada kecendrungan bahwa tidak sedikit para pelaku bisnis yang keluar dari kerangka syariah dalam menjalankan usahanya. Dengan demikian, apabila para pengusaha ingin menjalankan

${ }^{2}$ Burhanuddin S., Pasar Modal Syariah: Tinjauan Hukum, (Yogyakarta: UII Press, 2009), h. 4-5. 
kegiatan bisnisnya berdasarkan pada prinsipprinsip syariah, maka sebelumnya harus memenuhi ketentuan hukum yang ditetapkan. ${ }^{3}$ Ketentuan hukum ini dapat diberlakukan, baik untuk perseroan yang baru akan berdiri maupun perseroan lama yang akan dikonversi. ${ }^{4}$

Menurut (Pasal 109) Undang-Undang Perseroan Terbetas (UUPT) Nomor 40 Tahun 2007, perseroan yang menjalankan kegiatan usaha berdasarkan prinsip syariah harus memenuhi persyaratan sebagai berikut: (a) Perseroan yang menjalankan kegiatan usaha berdasarkan prinsip syariah selain mempunyai Dewan Komisaris wajib mempunyai Dewan Pengawas Syariah; (b) Dewan Pengawas Syariah sebagaimana dimaksud pada ayat (1) terdiri atas seorang ahli syariah atau lebih yang diangkat oleh RUPS atas rekomendasi Majelis Ulama Indonesia; (c) Dewan Pengawas Syariah sebagaimana dimaksud pada ayat (1) bertugas memberikan nasihat dan saran kepada direksi serta mengawasi kegiatan perseroan agar sesuai dengan prinsip syariah. Ketentuan pasal di atas bersifat umum, dalam arti berlakunya dapat meliputi perseroan perseorangan maupun persekutuan. Bahkan dengan mengacu pada pasal itu, berarti DSNMUI telah diberi kewenangan lebih lanjut untuk merumuskan peraturan bagaimana menerapkan prinsip-prinsip syariah ke dalam organisasi bisnis/perseroan. ${ }^{5}$

Perseroan sebagai badan usaha dapat didirikan oleh seseorang pengusaha maupun beberapa pengusaha secara bersama sama. Perseroan yang didirikan dan dimiliki oleh seorang pengusaha yang mempunyai cukup modal untuk berusaha disebut perseroan perseorangan. Kemudian perseroan dikatakan persekutuan jika didirikan oleh beberapa pengusaha yang mengikatkan diri dalam perjanjian. $^{6}$ Berbeda dengan perseroan perseorangan, untuk mendirikan perusahaan persekutuan/ perseroan berdasarkan prinsipprinsip syariah, maka landasan akad yang harus

\footnotetext{
${ }^{3}$ Ketentuan hukum ini dapat ditetapkan oleh lembaga pemerintah berdasarkan petunjuk (fatwa) Dewan Syariah Nasional Majelis Ulama Indonesia (DSN-MUI).

${ }^{4}$ Burhanuddin S., Hukum Bisnis Syariah, (Yogyakarta: UII Press, 2011), h. 17-18.

${ }^{5}$ Burhanuddin S., Hukum Bisnis Syariah, h. 17-18.

${ }^{6}$ Burhanuddin S., Hukum Bisnis Syariah, h. 18-19.
}

digunakan oleh para pengusaha adalah syirkah. $^{7}$

Untuk melakukan persekutuan usaha dalam mencari penghidupan, akad utama yang digunakan adalah syirkah. Meskipun akad syirkah dapat kita jumpai dalam berbagai kitab fiqh, namun kenyataan untuk mendirikan perseroan/ korporasi modern di Indonesia tidak pernah mendasarkan pada akad syirkah. Adapun yang menjadi sebab utamanya adalah bahwa akad syirkah tidak diadopsi ke dalam undang-undang perseroan yang berlaku saat ini. Adanya pemberlakuan Pasal 109 UUPT hanya sebatas kewajiban adanya DPS agar perseroan dalam menjalankan usaha tidak bertentangan dengan prinsip-prinsip syariah dan belum menyetuh prinsip-prinsip bagaimana mendirikan perseroan itu sendiri. Kemudian yang menjadi pertanyaan, mungkinkan konsep syirkah diimplementasikan dalam perseroan modern.

Untuk mendirikan perseroan modern, diperlukan pola hubungan hukum (perikatan) yang menyeluruh, yaitu mulai dari perikatan antara masing-masing pihak sebagai pendiri perseroan (the owners), perseroan dengan investor, perseroan dengan karyawannya, perusahan dengan perseroan lainnya, hingga perseroan dengan konsumennya. Untuk membentuk pola hubungan hukum tersebut, diperlukan berbagai akad yang berfungsi sebagai underlying contract.

Meskipun hubungan hukum pada perseroan modern sangat rumit, namun sesungguhnya akad syirkah tetap dapat diimplementasikan. Agar dapat diimplementasikan, akad syirkah perlu dikembangkan secara lebih lanjut (menggunakan metode induktif) tanpa harus mengubah rukun dan syarat-syaratnya. Pendekatan ini juga sudah dilakukan untuk menerapkan akad-akad muamalah lainnya ke dalam produk-produk lembaga keuangan modern. Pengadopsian akad-akad yang diterapkan ke dalam produk keuangan syariah telah mengalami pengembangan, bahkan

\footnotetext{
${ }^{7}$ Pengertian syirkah adalah suatu perjanjian antara dua orang atau lebih yang bersepakat untuk menjalankan usaha bersifat finansial dengan tujuan memperoleh keuntungan. Lihat: Taqiyuddin An-Nabhani, AnNizham al-Iqtishadi fi Al-Islam, (Beirut: Darul Ummah, 2004), h. 146.
} 
modifikasi antara akad yang satu dengan akad yang lainnya.

Kenyataan bahwa akad syirkah banyak dikaji dalam kitab-kitab fiqh karya ulama baik mutaqadimin maupun mutakhirin (kontemporer). Diantara ulama mutaqadimin yang membahas bab syirkah adalah para imam mazhab seperti Abu Hanifah $(80 \mathrm{H}-150 \mathrm{H})$, Imam Malik (93H - 179H), Imam Syafi'I $(150 \mathrm{H}-204 \mathrm{H})$ dan Imam Hambali (164H 241H), serta pengikut-pengikut mereka. Masing-masing mazhab tersebut memiliki kesamaan dan perbedaan pendapat tentang bentuk-bentuk syirkah. Apa yang menjadi dasar hukum perbedaan pendapat masingmasing mazhab terkait bentuk-bentuk syirkah, merupakan persoalan yang menarik untuk diteliti sebelum diterapkan dalam konteks modern.

Pada dasarnya sebab munculnya perbedaan pendapat di kalangan manusia adalah tentang memaknai hakikat kebenaran. Kemudian munculnya sebab perbedaan antara umat muslim adalah pada manhaj pemikiran terkait persepsi tentang Islam. Namun apabila ada ketetapan berlaku yang tidak boleh seorangpun mengingkarinya, maka janganlah manusia mengingkarinya. ${ }^{8}$ Tentu apa yang menjadi perbedaan pendapat dari para imam mazhab adalah bukan pada wilayah ushul yang sudah tetapkan dalam nash-nash syar'i melainkan wilayah furûiyah semata.

Terjadinya perbedaan pemikiran fiqh berasal dari suatu ajaran fiqh yang kemudian menjadi mazhab fiqh. Perlu diinformasikan bahwa perbedaan mazhab bukanlah pada esensi agama maupun syariah, akan tetapi hanya pada tataran perbedaan memahami nash-nashnya untuk menerapkan semua cabang-cabangnya (al-furû'). Semua perbedaan akan menyatu terhadap upaya mensucikan ayat-ayat al-Quran dan al-Sunnah. Akan tetapi bagian dari keutamaan mengikuti Islam ialah sebagian besar mereka tidak membolehkan menyalahi pendapat para sahabat yang menyaksikan dan melihat proses pewahyuan. Penerimaan ilmu dari Nabi Saw telah membawanya pada perbedaan, yaitu perbedaan bukan pada ushulnya tetapi pada cabangnya. Karenanya

\footnotetext{
${ }^{8}$ Muhammad Abu Zahrah, Târikh al-Mazâhib alIslâmiyah: Al-Siyasat al-Aqâid wa Târīkh al-Mazâgib alFiqhiyah (Cairo: Dar al-Fikri al-Arabi, t.t.), h. 7.
}

tidak ada dalil yang jelas untuk ikhtilaf. Sebagai contoh pendapat mereka yang dinisbatkan pada syariah adalah bagikan ranting dari pepohonan. ${ }^{9}$

Dengan mengacu pada surat AnNisa'[4]:59, perbedaan pendapat sangat mungkin terjadi. Namun apabila terjadi perbedaan pendapat, Allah memerintahkan agar kembali kepada al-Quran dan al-Sunnah. ${ }^{10}$ Para ulama telah memperingatkan bahayanya perbedaan pendapat (al-ikhtilâf) dalam segala bentuknya melalui menegaskan kewajiban untuk menjauhinya. Ibnu Mas'ud r.a menyatakan bahwa al-khilâf adalah keburukan. Al-Sabaki mengatakan bahwa rahmat adalah kewajiban menghilangkan perbedaan pendapat. ${ }^{11}$ Berdasarkan peringatan tersebut dapat diambil hikmah bahwa menghindari perbedaan pendapat lebih diutamakan dari melakukannya. Rahmat Allah lebih dekat pada kesatuan pendapat dari pada perbedaan. Kalaupun kenyatannya ada perbedaan pendapat, tentu ada batas-batas kebolehan dan keharamannya.

Sesungguhnya perbedaan pendapat imam mazhab adalah kebanyakan hanya pada persoalan ijtihad, sebagaimana perbedaan para sahabat dan tabi'in sebelumnya. Mereka semua dalam hidayah selama berbeda pendapat, bukan berasal dari nafsu syahwat atau keingingan berselisih. Seseorang yang menawarkan usaha yang bukan dalam kapasitasnya, janganlah memaksakan tujuannya, kecuali untuk mencapai kebenaran mencapai ridha Allah. Karenanya seseorang ahlul ilm dalam perjalannya selalu mengekspresikan penerimaannya terhadap fatwa para mufti

\footnotetext{
${ }^{9}$ Muhammad Abu Zahrah, Târikh al-Mazâhib alIslâmiyah: Al-Siyasat al-Aqâid wa Târīkh al-Mazâgib alFiqhiyah (Cairo: Dar al-Fikri al-Arabi, t.t.), h. 277.

${ }^{10}$ Hai orang-orang yang beriman, taatilah Allah dan taatilah Rasul (nya), dan ulil amri di antara kamu. Kemudian jika kamu berlainan pendapat tentang sesuatu, Maka kembalikanlah ia kepada Allah (Al Quran) dan Rasul (sunnahnya), jika kamu benar-benar beriman kepada Allah dan hari kemudian. yang demikian itu lebih utama (bagimu) dan lebih baik akibatnya (QS.An-Nisa'[4]:59).

${ }^{11}$ Taha Jabir 'Alawani, Adab al-Ikhtilâf fi al-Islâmī, (Herndon: The Institute of Islamic Thought, 1992), h. 30.
} 
untuk berbagai persoalan ijtihad sepanjang berkompeten. ${ }^{12}$

Para imam mazhab adalah fuqaha yang berkompeten sehingga banyak umat Islam yang mengikuti pendapat-pendapatnya. Alawani membagi imam mazhab menjadi dua, yaitu yang kategori fuqaha hadits ialah Maliki, Syafi'i, Hambali yang kesemuanya menerima fiqh di Madinah, sedangkan Abu Hanifah mewarisi fiqh ahlul ra'yi. ${ }^{13}$ Masing-masing imam mazhab tersebut memiliki pengikut yang karya-karyanya merujuk pada fiqh mereka. Karya-karya imam mazhab dan para pengikutnya kemudian banyak dikutip ulama mutakhirin (kontemporer) melalui pendekatan perbandingan. Salah satu perbedaan pendapat yang termuat dalam karya-karyanya ulama mazhab adalah terkait dengan bentuk syirkah.

Dalam al-Quran dan al-Hadits terdapat dalil-dalil syara' yang dapat menjadi dasar hukum berlakunya syirkah. Dari dalil-dalil tersebut para ulama berijma' bahwa syirkah hukumnya boleh. Namun sebagaimana kita diketahui, dalil-dalil tentang syirkah masih bersifat umum sehingga masih membuka peluang untuk melakukan ijtihad. Para imam mazhab ketika itu sudah melakukan ijtihad untuk menentukan konsep syirkah, mulai dari ta'rif, arkân wa syurûtuha, anwâul syarikât wa ahkâmuhâ dan lain-lain. Namun ternyata upaya ijtihad para imam mazhab pada waktu itu menghasilkan bentuk syirkah yang berbedabeda. Perbedaan inilah yang kemudian menimbulkan pertanyaan, mana sesungguhnya bentuk syirkah yang paling syar'i untuk diimplementasikan dalam konteks perseroan modern.

\section{Mengenal Konsep Syirkah}

Syirkah dari segi bahasa berarti percampuran (khalat) dua bagian atau lebih sehingga tidak dapat dibedakan lagi antara satu bagian dengan bagian lainnya. Sedangkan menurut syara', syirkah adalah transaksi antara dua orang atau lebih yang masing-masing pihak sepakat untuk melakukan kerja yang bersifat financial dengan tujuan mencari

\footnotetext{
${ }^{12}$ Taha Jabir 'Alawani, Adab al-Ikhtilâf fi al-Islâmī, (Herndon: The Institute of Islamic Thought, 1992), h. 116.

${ }^{13}$ Taha Jabir 'Alawani, Adab al-Ikhtilâf fi al-Islâmī, (Herndon: The Institute of Islamic Thought, 1992), h. 89.
}

keuntungan. ${ }^{14}$ Meskipun dari segi istilah memiliki makna yang sama, masing-masing mazhab mempunyai definisi yang berbedabeda tentang syirkah.

Kehidupan manusia membutuhkan adanya kerjasama antara satu sama lainnya. Kerjasama dapat diwujudkan melalui berbagai bentuk baik prilaku perbuatan (al-adabī) maupun materi (al-mâd$\vec{\imath})$ Kerjasama menggunakan materi merupakan bagian dari al-mu'âmalât al-mâliyah yang secara fitrah bertujuan untuk memenuhi kebutuhan hidup. Ketentuan tersebut terkait dengan hubungan sesama manusia yang mengharuskan adanya persekutuan antara dua orang lebih dalam hal kepemilikan harta, penggunaanya, dan lain sebagainya. Bentuk persekutuan diantara manusia yang merupakan bagian dari mu'âmalat disebut syirkah. ${ }^{15}$

Pemerintahan Firaun di Babilonia telah mengenal syirkah. Konsep syirkah pada waktu itu telah termuat dalam undang-undang Hamurabi yang berlaku seratus tahun sebelum masehi. Sebagian hukum-hukum tentang syirkah telah berlaku pada zaman itu. Abu Dawud dan Ibn Majah meriwayatkan dari Ibnu كنت Abi Saib r.a bahwa Rasulullah bersabda

$$
\text { شريكى في الجاهلية فكنت خير شريك لا تدارينين }
$$

16 مari hadits tersebut dinyatakan

bahwa meskipun syirkah berlaku sejak zaman jahiliyah, namun keberadaanya dapat mendatangkan kebaikan selama dilakukan dengan sungguh-sungguh dan tidak berbuat kerusakan.

Rumawi juga telah memasukan syirkah ke dalam system perundang-undangan di mana antara akad syirkah khusus dengan pendahuluannya ada perjanjian keridhaan (radhâ̄i). ${ }^{17}$ Kemudian setelah Islam datang, syirkah dipraktikkan diantara orang-orang arab. Telah menjadi tabiat kehidupan ekonomi perlu

\footnotetext{
${ }^{14}$ Taqiuddin An-Nabhani, Al-Nidhâm al-Iqtishâdī fi alIslâmi, (Beirut: Dar al-Umah, 1425H), h. 148.

${ }^{15}$ Abdul Aziz Al-Khiyad, Syarikât fì Asy-Syarīah alIslâm wa al-Qânûni al-Wad'’,, (Aman: Dar al-Basyir, 1993), h. 25.

${ }^{16}$ Ali Al-Khafifi, Syarikât fì al-Fiqh al-Islâmi: Buhûts Muqâranah, (Kairo: Darul Fikri al-Arabi, 2009), h. 27.

${ }^{17}$ Abdul Aziz Al-Khiyad, Syarikât fì Asy-Syarīah alIslâm wa al-Qânûni al-Wad'’̄, (Aman: Dar al-Basyir, 1993), h. 27
} 
adanya kerjasama mengembangkan harta dan investasi diantara manusia. Karena alasan kebutuhan tersebut terutama orang-orang arab quraisy saat itu, kemudian disyariatkan akad syirkah. $^{18}$ Akad syirkah disyariatkan Allah karena tidak semua usaha mampu dijalankan melalui usaha perseorangan. Dalam usaha tertentu, diperlukan adanya kerjasama/ persekutuan yang melibatkan pihak lain. AlQuran melalui kisah Dawud telah menjelaskan keberadaan syirkah.

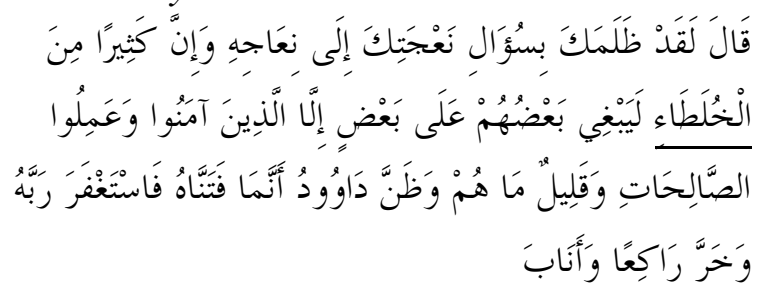

Dan sesungguhnya kebanyakan dari orangorang yang bersekutu itu sebagian mereka berbuat zalim dengan sebagian yang lain, kecuali orang-orang yang beriman dan mengerjakan amal saleh, dan hanya sedikitlah mereka ini (QS.Shaad[38]:24).

Yang dimaksud al-khulathâi adalah syirkah. ${ }^{19}$ Sesungguhnya kebanyakan orang yang bersyirkah saling melampaui batas satu dengan lainnya, kecuali orang-orang yang beriman dan beramal shaleh dengan ketaatan kepada Allah.

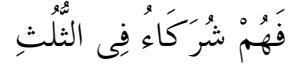

Maka mereka telah bersekutu dalam yang sepertiga (QS.An-Nisa[4]:12).

Islam telah menetapkan bentuk mu'âmalah dan tijârah yang menjadi kebutuhan manusia yaitu syirkah. $^{20}$ Disamping itu, dalam hadits qudsinya Rasulullah Saw bersabda:

$$
\begin{aligned}
& \text { إن الله عزوجل يقول: أنا ثالث الشريكين مالم يخن أحد هما } \\
& \text { صاحبه فاذا خَانه خرجت من بينهما (رواه ابو داود عن أبي }
\end{aligned}
$$

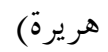

Sesungguhnya Allah SWT berfirman: Aku adalah pihak ketiga dari dua orang yang berserikat, sepanjang salah seorang dari

\footnotetext{
${ }^{18}$ Abdul Aziz Al-Khiyad, Syarikât fì Asy-Syarī'ah alIslâm wa al-Qânûni al-Wad'̄̄, (Aman: Dar al-Basyir, 1993), h. 28.

${ }^{19}$ Sayid Sabiq, Fiqh Sunnah, (Kairo: Fatul 'Ilam AlArabi, t.t.), Jilid III, h. 294.

${ }^{20}$ Sayid Sabiq, Fiqh Sunnah, (Kairo: Fatul 'Ilam AlArabi, t.t.), Jilid III, h. 294.
}

keduannya tidak menghianati. Jika seseorang menghianati maka Allah keluar dari keduannya (HR. Abu Dawud dari Abu Hurairah r.a).

Maksud hadits tersebut adalah bahwa Allah memberkati kedua pihak yang bersyirkah harta, serta memberikan perlindungan kepada keduanya selama diantara salah satu pihak tidak ada yang menghianati. Karenanya apabila salah satu pihak menghianatinya, maka Allah akan mencabut keberkahan dari harta tersebut. $^{21}$

$$
\text { يَدُ الله عَلَى الشَرِيْكَيْنِ آلَمْ يَتَخَاوَنَا (رواه البخارى و مسلم) }
$$

Pertolongan Allah tercurah atas dua pihak yang berserikat, sepanjang keduannya tidak saling berkhianat (HR. Bukhari dan Muslim).

\section{Bentuk Syirkah Menurut Al-Mazâhib Al- Arba'ah}

Meskipun kaum muslimin bersepakat bahwa syirkah hukumnya boleh, namun berbeda pendapat dalam hal pembagian bentuknya. $^{22}$ Menurut Abdurraham Al-Jaziri dalam Kitâb al-Fiqh 'alâ al-Mazâhib alArba'ah, Hanifiyah membagi syirkah menjadi menjadi dua, yaitu syirkah melalui kepemilikan (syirkah milk) dan syirkah melalui perikatan (syirkah 'ukûd). Syirkah milk, yaitu kepemilikan dua orang atau lebih tanpa melalui perikatan. ${ }^{23}$ Kemudian syirkah milk terbagi menjadi syirkah jabari dan ihtiyâri. Adapun syirkah jabari yaitu bergabungnya dua orang atau lebih dalam kepemilikan harta benda tanpa usaha, seperti harta warisan. ${ }^{24}$ Sedangkan syirkah ikhtiyâri yaitu berkumpulnya harta benda melalui usaha kedua pihak, seperti

\footnotetext{
${ }^{21}$ Sayid Sabiq, Fiqh Sunnah, (Kairo: Fatul 'Ilam AlArabi, t.t.), Jilid III, h. 294.

${ }^{22}$ Wahbah Zuhaily, Al-Figh al-Islâm̄ wa Adilatuhu, (Beirut: Dar al-Fikr, t.t.), Jilid IV, h. 793.

${ }^{23}$ Termasuk syirkah milk secara ikhtiyâri adalah saling menerima wasiat dalam hal harta. Lihat Abdurrahman alJaziri, Kitâb al-Fiqh 'ala al-Mazâhib al-Arba'ah, (Beirut: Darul Kitab al-Ilmiah, 1424H), Jilid 3, h. 60.

${ }^{24}$ Abdurrahman al-Jaziri, Kitâb al-Fiqh 'ala al-Mazâhib al-Arba'ah, (Beirut: Darul Kitab al-Ilmiah, 1424H), Jilid 3, h. 60 .
} 
percampuran harta hasil kerjasama transaksi jual beli. ${ }^{25}$

Menurut Sayid Sabiq dalam kitab Fiqh Sunnah, syirkah milk hukumnya tidak boleh karena masing-masing partisipan dapat mentasyarruf-kan bagian hartanya tanpa izin, karenanya pihak lain seolah-olah orang asing yang tidak memiliki kewenangan terhadap harta tersebut. ${ }^{26}$ Sedangkan menurut Wahbah Zuhaily dalam kitab Al-Fiqh al-Islâmī wa Adilatuhu, menyatakan bahwa masing-masing pihak dalam syirkah milk dengan segala bentuknya bagaikan orang asing, sehingga tidak boleh men-tasyarruf-kan harta tanpa izin jika bukan menjadi kewenanganya. ${ }^{27}$

Syirkah 'ukîd yaitu suatu akad yang terjadi antara dua pihak atau lebih untuk bersekutu dalam hal harta dan keuntungan. ${ }^{28}$ Menurut Hanabilah, syirkah terdiri dari lima macam, yaitu syirkah 'inân, mufâwadhah, abdân, wujûh dan mudhârabah. Sedangkan menurut Hanafiyah, syirkah terdiri dari enam macam, yaitu syirkah amwâl, a'mâl, dan wujûh. Kemudian dari masing-masing syirkah tersebut dibagi menjadi mufâwadhah dan 'inân. Menurut pendapat Mâlikiyah dan Syâfi'iyah, syirkah terbagi menjadi empat macam, yaitu syirkah 'inân, mufâwadhah, abdân dan wujûh. ${ }^{29}$ Adanya perbedaan pembagian bentuk tersebut tentu menimbulkan pendapat hukum yang berbeda pula. Karenanya mengetahui alasan masing-masing fuqaha adalah sangat

\footnotetext{
${ }^{25}$ Abdurrahman al-Jaziri, Kitâb al-Fiqh 'ala al-Mazâhib al-Arba'ah, (Beirut: Darul Kitab al-Ilmiah, 1424H), Jilid 3, h. 60 .

${ }^{26}$ Sayid Sabiq, Fiqh Sunnah, (Kairo: Fatul 'Ilam AlArabi, t.t.), Jilid III, h. 295

${ }^{27}$ Dalam hal ini Zuhaily mengutip kitab Badâ' $i$ : VI/56, Al-Mabsût: XI/151, Tabyīn al-Haqâ'iq: III/312. Lihat Wahbah Zuhaily, Al-Fiqh al-Islâmī wa Adilatuhu, (Beirut: Dar al-Fikr, t.t.), Jilid IV, h. 794

${ }_{28}$ Wahbah Zuhaily, Al-Fiqh al-Islâmī wa Adilatuhu, (Beirut: Dar al-Fikr, t.t.), Jilid IV, h. 794.

${ }^{29}$ Wahbah Zuhaily, Al-Fiqh al-Islâmī wa Adilatuhu, h. 794-795; dalam hal ini melalui kitabnya Zuhaily mengutip Ibn Rusyd, Bidayah Al-Mustahid: II/248 dan Mughī Muhtâj: II/212. Lihat pula Gufran A. Masadi, Fiqh Muamalah Kontekstual, (Jakarta: Rajawali Press, 2002), h. 193; Rachmat Syafe'i, Fiqh Muamalah, (Bandung: Pustaka Setia, 2000), h. 187. Sayid Sabiq membagi bentuk syirkah 'ukûd menjadi empat macam, yaitu syirkah 'inân, mufâwadhah, 'abdân, dan wujûh. Sayid Sabiq, Fiqh Sunnah, (Kairo: Fatul 'Ilam Al-Arabi, t.t.), Jilid III, h. 29
}

penting sebelum penulis mengambil kesimpulan.

Para ulama fiqh bersepakat dalam hal kebolehan syirkah 'inân, namun untuk syirkah lainnya masih diperselisihkan ke-syar'iahannya. Syafi'iyah, termasuk Zahiriyah dan Imamiyah menganggap semua bentuk syirkah hukumnya batil kecuali 'inân dan mudhârabah. Sedangkan Hanabilah membolehkan semua syirkah kecuali syirkah mufâwadhah. Malikiyah membolehkan semua syirkah kecuali syirkah wujûh. Hanafiyah dan Zaidiyah cendrung membolehkan semua syirkah selama memenuhi rukun dan syaratnya. ${ }^{30}$ Meskipun mudhârabah merupakan bagian dari syirkah, namun tidak masuk dalam pembahasan ini. Berikut adalah beberapa argumentasi yang dibangun oleh masingmasing mazhab terkait bentuk-bentuk syirkah.

Syirkah 'Inân

Syirkah 'inân adalah persekutuan modal antara dua pihak untuk menjalankan usaha. Apabila usahanya memperoleh keuntungan, maka akan dibagi diantara keduanya. Dalam hal ini tidak menyaratkan adanya kesamaan modal, tasyarruf dan pembagian keuntungan. Modal salah satu pihak boleh lebih besar dari pihak lainnya, begitupula dalam hal tanggung jawabnya. Kebolehan kesamaan pembagian keuntungan seperti halnya kebolehan perbedaannya berdasarkan atas kesepakatan diantara mereka. ${ }^{31}$ Menurut Zuhaily, Syirkah 'inân hukumnya boleh secara ijma'. Adapun perbedaanya terdapat pada syarat-syaratnya sebagaimana pada penamaannya. ${ }^{32}$

Syirkah Mufâwadhah

Mufâwadhah secara bahasa berarti kesamaan (al-musâwâh). ${ }^{33}$ Sedangkan secara istilah yaitu perikatan antara dua orang atau lebih melalui persekutuan usaha dengan syarat adanya kesamaan modal, tasyarruf, dan tanggungjawabnya terhadap hutang. Masingmasing partner menjadi penjamin (kafilân) partner lainnya dalam melakukan transaksi jual

\footnotetext{
30 Wahbah Zuhaily, Al-Fiqh al-Islâmī wa Adilatuhu, (Beirut: Dar al-Fikr, t.t.), Jilid IV, hlm. 795

31 Sayid Sabiq, Fiqh Sunnah, (Kairo: Fatul 'Ilam AlArabi, t.t.), Jilid III, h. 296

${ }^{32}$ Wahbah Zuhaily, Al-Fiqh al-Islâmī wa Adilatuhu, h. 796

${ }^{33}$ Wahbah Zuhaily, Al-Fiqh al-Islâmī wa Adilatuhu, h. 797.
} 
beli. Masing-masing partner terikat dengan kewajiban partner lainnya terkait klaim selama bertransaksi. Apa yang menjadi kewajiban salah satu partner menjadi kewajiban partner lainnya, yaitu keduanya saling tergabung dalam berbagai hak dan kewajiban yang terkait dengan transaksi di dalamnya. ${ }^{34}$

Hanifiyah dan Zaidiyah membolehkan syirkah mufâwadhah dengan mengutip hadits yang menyatakan: (فاوضوا), (إذا تفاوضتم فأحسنو ا المفاوضة) Begitupula Malikiyah juga membolehkan syirkah mufâwadhah meskipun tanpa menyebutkan maksud seperti Hanifiyah. $^{36}$ Tidak ada perbedaan pendapat antara Imam Malik dengan Abu Hanifah terkait dengan syarat mufâwadhah. Menurut Abu Hanifah, salah satu syarat mufâwadhah adalah kesamaan dalam hal jumlah modal. Karenanya menurut Imam Malik, tanpa adanya syarat kesamaan modal berarti identik dengan syirkah 'inân. ${ }^{37}$ Sedangkan yang tidak membolehkan syirkah mufâwadhah adalah Syafi'iyah, Hanabilah, dan jumhur fuqaha, disebabkan akad tersebut tidak ada dalil syar'inya. Memberlakukan syarat kesamaan dalam syirkah ini merupakan sesuatu yang sulit, karenanya di dalam syirkah tersebut terkadung unsur gharâr dan jahâlah. ${ }^{38}$ Syâfi'iyah tidak membolehkan dengan mengatakan: "Jika tidak menjadikan syirkah mufâwadhah sebagai sesuatu yang batil, maka sungguh batil pengetahuannya di dunia." 39

Syirkah Wujûh

Syirkah wujûh yaitu pembelian yang dilakukan oleh dua orang atau lebih tanpa

\footnotetext{
${ }^{34}$ Wahbah Zuhaily, Al-Fiqh al-Islâmī wa Adilatuhu, h. 798.

35 Dalam kitab ini Zuhaily mengutip pendapat yang mengatakan bahwa hadits tersebut gharib yakni tidak ada sumbernya. Kemudian berusaha mencari asal usul hadits tersebut. Ibnu Majah melalui jalan sahabat menyatakan, bahwa Rasulullah Saw bersabda: Tiga hal yang di dalamnya ada keberkahan, yaitu jual beli tangguh, muqaradah, menampurkan tepung dengan gandum bukan untuk dijual. Wahbah Zuhaily, Al-Fiqh al-Islâmī wa Adilatuhu, h. 800.

${ }^{36}$ Wahbah Zuhaily, Al-Fiqh al-Islâmī wa Adilatuhu, h. 800 .

37 Ibn Rusyd, Bidâyah Al-Mustahid:Nihâyah alMuqtashid, (Beirut: Dar al-Fikr, 2005), Jilid II, h. 205

${ }^{38}$ Wahbah Zuhaily, Al-Figh al-Islâmī wa Adilatuhu,. h. 801.

${ }^{39}$ Sayid Sabiq, Fiqh Sunnah, h. 296.
}

menggunakan modal melainkan menggantungkan pada kepercayaan dan keahliannya dalam berdagang. Syirkah antara mereka ialah untuk mencari keuntungan yaitu syirkah melalui kesepakatan tanpa profesi maupun harta. Menurut Hanafiyah dan Hanabilah syirkah wujûh hukumnya boleh karena mengerjakan suatu pekerjaan boleh hukumnya. Masing-masing yang terikat perjanjian boleh berbeda kepemilikan terhadap sesuatu yang ditransaksikan. Adapun apabila memperoleh kuntungan, maka akan dibagi diantara keduanya sesuai porsi (konstribusi) masing-masing dalam kepemilikan. Namun Syafi'iyah dan Malikiyah membatalkannya, karena suatu syirkah sesungguhnya terkait dengan harta dan pekerjaan. ${ }^{40}$ Ibnu Rusy dalam kitab Bidâyah Al-Mustahid: Nihâyah al-Muqtashid menyatakan bahwa syirkah wujûh merupakan bentuk jaminan kepada pelaku usaha yang tidak memiliki modal. Kemudian ia mengutip Imam Malik dan Syafi'I yang menyatakan bahwa syirkah harus terkait dengan harta dan pekerjaan. Tanpa adanya kedua unsur tersebut dalam masalah syirkah dapat menimbulkan gharâr. Dikatakan demikian karena masingmasing pihak saling bertukar pekerjaan tanpa adanya pembatasan profesi dan kekhususan pekerjaan. $^{41}$

\section{Syirkah Abdân}

Syirkah abdân adalah kesepakatan antara dua pihak terhadap suatu penerimaan pekerjaan yang dapat mendatangkan upah untuk dibagi diantara keduanya sesuai kesepakatan. ${ }^{42}$ Dalil kebolehan syirkah ini adalah apa yang diriwayatkan Abu 'Ubaidah dari Abdullah yang menyatakan:

$$
\begin{aligned}
& \text { اشتركت وأنا وعمار و سعد فيما نصيب يوم بدر, قال: } \\
& \text { فجاء سعد بأسيرين و لم أجىء أنا وعمار بشيء (رواه أبو } \\
& \text { داود و النسائي و ابن ماجة). }
\end{aligned}
$$

Syirkah abdân hukumnya boleh menurut Malikiyah, Hanifiyah, Hanabilah, dan Zahidiyah. Karena maksud dari syirkah tersebut adalah untuk menghasilkan

\footnotetext{
${ }^{40}$ Sayid Sabiq, Fiqh Sunnah, h. 296-297.

41 Ibn Rusyd, Bidâyah Al-Mustahid: Nihâyah alMuqtashid, h. 206.

${ }^{42}$ Sayid Sabiq, Fiqh Sunnah, h. 297

${ }^{43}$ Sayid Sabiq, Fiqh Sunnah, h.297.
} 
keuntungan. Dan hal itu mungkin terjadi melalui pemberdayaan. Sesungguhnya manusia saling menjalankan usaha baik melalui syirkah harta maupun dengan pekerjaan seperti halnya mudhârabah. Dan itu merupakan salah satu dari berbagai macam pekrjaan. $^{44}$ Menurut Syafi'i, bentuk syirkah ini hukumnya batil, karena suatu syirkah di dalamnya harus mengkhususkan pada harta bukan pada pekerjaan. $^{45}$

Tabel:

Pendapat Al-Mazâhib Al-Arba'ah tentang Bentuk Syirkah

\begin{tabular}{|lcccc|}
\hline $\begin{array}{l}\text { Al- } \\
\text { Mazâhib } \\
\text { Al- } \\
\text { Arba'ah }\end{array}$ & $\begin{array}{c}\text { Syirkah } \\
\text { 'Inân }\end{array}$ & $\begin{array}{c}\text { Syirkah } \\
\text { Mufâwadhah }\end{array}$ & $\begin{array}{c}\text { Syirkah } \\
\text { Abdân }\end{array}$ & $\begin{array}{c}\text { Syirkah } \\
\text { Wujûh }\end{array}$ \\
\hline Mâlikiyah & $\sqrt{ }$ & $\sqrt{ }$ & $\sqrt{ }$ & \\
\hline Syâfi'iyah & $\sqrt{ }$ & $\mathrm{X}$ & $\mathrm{X}$ & $\mathrm{X}$ \\
\hline Hanâbilah & $\sqrt{ }$ & $\mathrm{X}$ & $\sqrt{ }$ & $\sqrt{ }$ \\
\hline Hanafiyah & $\sqrt{ }$ & $\sqrt{ }$ & $\sqrt{ }$ & $\sqrt{ }$ \\
\hline
\end{tabular}

Catatan:

$\begin{array}{ll}\sqrt{ } & : \text { Sah } \\ \mathrm{X} & : \text { Tidak sah }\end{array}$

Dalam kitab Al-Rûdhat Al-Nadiyah, sebagaimana dikutip Sayid Sabiq, dinyatakan bahwa penamaan yang terjadi pada kitab-kitab furu' tentang bentuk-bentuk syirkah, seperti mufâwadhah, 'inân, wujûh, dan abdân, tidaklah disebutkan secara syar'iyah maupun lughaiyah. Tetapi istilah-istilah tersebut terjadi suatu pembaruhan. Tidak ada larangan bagi kedua pihak untuk menggabungkan hartanya atau bisnisnya sebagaimana dia memaknai istilah mufâwadhah. ${ }^{46}$ Karena bentuk-bentuk syirkah secara istilah tidak disebutkan dalam nashnash, berarti Allah memberi peluang kepada hamba-hambaNya untuk melakukan ijtihad. Apa yang dilakukan Al-Mazâhib Al-Arba'ah terkait bentuk-bentuk syirkah merupakan bagian dari ijtihad.

\section{Implementasi Syirkah dalam Konteks Modern}

Syirkah merupakan praktik muamalah masa jahiliyah yang diadopsi ke dalam Islam. Dalam fiqh Islam, hukum asal dari syirkah

\footnotetext{
${ }^{44}$ Wahbah Zuhaily, Al-Fiqh al-Islâmī wa Adilatuhu,. h. 803.

${ }^{45}$ Sayid Sabiq, Fiqh Sunnah, h. 297.

${ }^{46}$ Sayid Sabiq, Fiqh Sunnah, h. 297.
}

adalah boleh. ${ }^{47}$ Landasan syariat kebolehan syirkah terdapat dalam kitab al-Qur'an, asSunnah dan ijma,. ${ }^{48}$ Kebolehan syirkah dapat dikembangkan ke dalam berbagai bentuk berdasarkan ijtihad sebagaimana dicontohkan oleh para fuqaha. Setelah merujuk para nashnash syara', pendapat para fuqaha dapat dijadikan referensi untuk pengembangan konsep syirkah dan implementasinya dalam konteks modern.

Untuk mengimplentasikan bentuk-bentuk syirkah diperlukan langkah-langkah tertentu, yaitu pertama, pastikan apakah masing-masing peserta persekutuan turut menjalankan perusahaan atau tidak. Apabila mereka keseluruhan turut menjalankan perusahaan secara langsung, maka akad yang digunakan adalah musyârakah. Jika akad musyârakah (syirkah) yang digunakan untuk mendirikan perusahaan, maka kemungkinan modal yang disertakan masing-masing pihak dapat berwujud: (a) Apabila modal yang disertakan masing-masing pihak berupa uang yang jumlahnya sama (Rp. X dan Rp. X) maka akad yang digunakan syirkah mufawadhah; (b) Apabila modal yang disertakan masing-masing pihak berupa uang dengan jumlah yang berbeda (Rp. X dan Rp. Y), maka akad yang digunakan syirkah 'inan; (c) Apabila modal yang disertakan masing-masing pihak berupa pekerjaan (al-a'mal), maka akad yang digunakan syirkah 'abdan; (d) Apabila masing-masing pihak menjalankan usaha tanpa modal melainkan sebatas reputasi/ kepercayaan, maka akad yang digunakan adakah syirkah wujuh. ${ }^{49}$

Kedua, apabila yang menjalankan perusahaan hanya pihak yang menyertakan tenaga (mudhârib), sedangkan pihak yang menyertakan modal harta (shâhib al-mâl) tidak ikut serta dalam menjalankan perusahaan, maka akad yang digunakan adalah mudhârabah. Dalam hal ini perlu dipahami, bahwa meskipun mudhârib hanya menyertakan tenaga, namun kedudukan mereka

\footnotetext{
${ }^{47}$ Dalam bermu'amalah, manusia tidak bisa lepas dari praktik syirkah. Karena kebutuhan itulah, praktik syirkah yang pernah dilakukan pada masa jahiliyah kemudian adopsi ke dalam fiqh Islam.

${ }^{48}$ Sayid Sabiq, Fiqh Sunnah, h. 297.

49 Burhanuddin S, Hukum Bisnis Syariah, (Yogyakarta: UII Press, 2011), h. 20-21.
} 
tetap sebagai pemilik perusahaan. Dikatakan demikian, karena mudhârib mendapatkan keuntungan bukan dari upah mengupah ('ujrah), melainkan dari bagi hasil persekutuan. Sedangkan pemberian upah (gaji), hanya berlaku bagi pekerja (karyawan) yang mengikatkan diri dengan perusahaan melalui akad ijârah. $^{50}$

Untuk membentuk perusahaan persekutuan berskala kecil, masing-masing syirkah biasanya digunakan sendiri-sendiri secara terpisah. Sedangkan untuk mendirikan perusahaan persekutuan berskala besar yang membutuhkan adanya hubungan perikatan hingga pada tingkat kerumitan tertentu, maka masing-masing syirkah tersebut boleh dipadukan satu dengan yang lainnya. Karena dalam setiap syirkah yang sah ketika berdiri sendiri, maka sah pula ketika digabungkan dengan jenis syirkah lainnya. ${ }^{51}$ Bahkan untuk menjalin hubungan perikatan antara perusahaan dengan pihak karyawan (pekerja), dibolehkan menggunakan akad lain di luar syirkah itu sendiri. Misalnya setelah para pengusaha sepakat membentuk perusahaan persekutuan, mereka dibolehkan untuk mengangkat karyawan sebagai pekerja. Dalam pengangkatan karyawan, akad yang digunakan oleh perusahaan bukan lagi syirkah dengan sistem bagi hasil, melainkan ijarâh dengan sistem gaji ('ujrah). Namun perlu diketahui, bahwa antara pemilik perusahaan yang satu dengan pemilik perusahaan yang lainnuya, secara hukum tetap dibolehkan melakukan persekutuan (syirkah). ${ }^{52}$

\section{Kesimpulan}

Syirkah merupakan praktik muamalah masa jahiliyah yang diadopsi ke dalam Islam. Menurut fiqh Islam, hukum asal dari syirkah adalah boleh. Landasan syariat kebolehan syirkah terdapat dalam kitab al-Qur'an, asSunnah dan ijma'. Meskipun kaum muslimin bersepakat tentang kebolehan syirkah, namun mereka berbeda pendapat dalam hal pembagian bentuknya, seperti mufâwadhah,'inân, wujûh, atau abdân. Perbedaan pendapat tersebut memiliki konsekuensi hukum yang berbeda pula. Namun perlu diketahui bahwa penamaan bentuk syirkah secara lughaiyah tidak dinyatakan dalam nash-nash syara' sehingga membuka peluang kita untuk melakukan ijtihad sebagaimana pernah dilakukan oleh al-mazâhib al-arba'ah. Bahkan melalui kombinasi dengan regulasi yang bersifat prosedural dan akad-akad lainnya, bentuk-bentuk syirkah tersebut dapat diterapkan dalam konteks modern.

\footnotetext{
${ }^{50}$ Burhanuddin S, Hukum Bisnis Syariah, (Yogyakarta: UII Press, 2011), h. 20-21.

51 Taqiyuddin An-Nabhani, An-Nizham al-Iqtishadi fi Al-Islam., h. 156.
}

\footnotetext{
${ }^{52}$ Burhanuddin S, Hukum Bisnis Syariah, h. 20-21.
} 


\section{DAFTAR PUSTAKA}

Alawani, Taha Jabir. Adab al-Ikhtilâf fi alIslâmī. Herndon: The Institute of Islamic Thought, 1992.

Al-Khiyad, Abdul Aziz. Syarikât fi AsySyarīah al-Islâm wa al-Qânûni alWad'̄, Aman: Dar al-Basyir, 1993.

Al-Khafifi, Ali. Syarikât fì al-Fiqh al-Islâmi: Buhûts Muqâranah, Kairo: Darul Fikri al-Arabi, 2009.

An-Nabhani, Taqiyuddin. An-Nizham alIqtishadi fi Al-Islam, Beirut: Darul Ummah, 2004.

Al-Jaziri, Abdurrahman. Kitâb al-Fiqh 'ala al-Mazâhib al-Arba'ah, Beirut: Darul Kitab al-Ilmiah, $1424 \mathrm{H}$.

Nyazee, Imran Ahsan Khan. Islamic Law of Business Organization (Partnerships),
Pakistan: The International of Islamic Thought, 2000.

Rusyd, Ibn. Bidâyah Al-Mustahid:Nihâyah alMuqtashid, Beirut: Dar al-Fikr, 2005.

Sabiq, Sayid. Fiqh Sunnah, Kairo: Fatul 'Ilam Al-Arabi, t.t.

S., Burhanuddin. Pasar Modal Syariah: Tinjauan Hukum, Yogyakarta: UII Press, 2009.

\section{Hukum Bisnis Syariah,} Yogyakarta: UII Press, 2011.

Zahrah, Muhammad Abu. Târikh al-Mazâhib al-Islâmiyah: Al-Siyasat al-Aqâid wa Târīkh al-Mazâgib al-Fiqhiyah, Cairo: Dar al-Fikri al-Arabi, t.t.

Zuhaily, Wahbah. Al-Fiqh al-Islâmī wa Adilatuhu, Beirut: Dar al-Fikr, t.t. 